\title{
PENGARUH UMUR SUMBER BAHAN STEK TERHADAP KEBERHASILAN STEK PUCUK MERANTI TEMBAGA (Shorea leprosula MIQ.)
}

\section{The effect age of cutting material resource to the success of rooted cuttings of Shorea leprosula MIQ.}

\author{
Danu $^{1)}$, Iskandar Z. Siregar ${ }^{2)}$, Cahyo Wibowo ${ }^{2)}$,dan/and Atok Subiakto ${ }^{3)}$ \\ ${ }^{1)}$ Balai Penelitian Teknologi Perbenihan Tanaman Hutan \\ (alamat2 lengkap mohon dicopykan dr artikel lain yg sama, yg \\ perbah ada sblmnya.. tks) \\ ${ }^{2)}$ Departemen Silvikultur, Institut Pertanian Bogor \\ ${ }^{3)}$ Pusat Penelitian dan Pengembangan Hutan dan Konservasi Alam
}

\begin{abstract}
Shorea leprosula is categorized as fast growing dipterocarps. Although classified as a promising species for plantation, there is still a problem in the application of large scale seedling procurement since the seed is characterized as recalcitrant and produced irregularly. Vegetative propagation is one of the promising techniques to overcome this problem. The main concern in vegetative propagation is the cutting material maturity or juvenility stage. The research was conducted with the objectives of determaining relation between age of stock plants reflecting various juvenile stages and the success of rooted cuttings. The results revealed that cuttings collected from 2 years old $S$. leprosula stock plants produced higher percentage of rooted cutting than those of older trees $(>10$ years old). The cutting ability to root was affected by $C / N$ ratio and IAA as shown from biplot analyses.
\end{abstract}

Key words: Cutting age, nutrition and auxin, rooted cuttings, Shorea leprosula

\begin{abstract}
ABSTRAK
Shorea leprosula Miq. merupakan tanaman dipterokarpa yang tergolong cepat tumbuh, namun benihnya bersifat rekalsitran dengan musim berbuah yang tidak menentu. Perbanyakan vegetatif merupakan salah satu alternatif untuk memperbanyak jenis ini. Umur tanaman menentukan tingkat juvenilitas dan kemampuan bahan stek untuk berakar. Penelitian ini bertujuan untuk mempelajari hubungan umur sumber bahan stek dengan kandungan hara dan auksin bahan stek terhadap keberhasilan perakaran stek S. leprosula. Bahan stek terdiri atas stek pucuk yang dikumpulkan dari pohon induk berumur $\leq 2$ tahun, 10 tahun dan 25 tahun. Hasil penelitian menunjukkan bahwa bahan stek dari pohon berumur $\leq 2$ tahun memiliki tingkat juvenilitas yang lebih tinggi dibandingkan dengan bahan stek dari tanaman dewasa (> 10 tahun) yang ditunjukkan dengan tingginya persen keberhasilan stek berakar, sejalan dengan dengan tingginya nisbah $\mathrm{C} / \mathrm{N}$ dan kandungan IAA dalam pucuk. Berdasarkan analisis biplot, kandungan IAA dalam
\end{abstract}


daun dan nisbah $\mathrm{C} / \mathrm{N}$ batang stek memberikan pengaruh yang lebih kuat terhadap keberhasilan perakaran stek pucuk S. leprosula.

Kata kunci: Umur bahan stek, hara dan auksin, stek pucuk, Shorea leprosula Miq.

\section{PENDAHULUAN}

Shorea lepropsula Miq. (meranti tembaga) merupakan salah satu jenis meranti dari famili Dipterocarpaceae yang tergolong cepat tumbuh, sehingga pohon ini sangat potensial untuk pengembangan hutan tanaman. Pohon ini tumbuh dominan di hutan tropis Asia Tenggara terutama Malaysia dan Indonesia. Di Indonesia pohon ini menyebar di wilayah Sumatera, Kalimantan dan Maluku. Di hutan alam jenis ini dapat mencapai diameter $100 \mathrm{~cm}$ dengan tinggi bebas cabang $30 \mathrm{~m}$. Kayunya dapat digunakan untuk berbagai keperluan seperti kayu lapis, kayu gergajian dan bahan bangunan (Ashton, 1992). Secara alami tanaman ini memiliki produktivitas $1,1-1,4 \mathrm{~m}^{3} / \mathrm{ha} / \mathrm{th}$, sedangkan pada hutan tanaman di Peninsular Malaysia dapat mencapai 7,7 m3/ha/th pada umur 35 tahun (Appanah and Weinland, 1993).

Benih meranti tembaga termasuk rekalsitran, sehingga benihnya hanya dapat disimpan dalam jangka pendek yaitu 6-12 minggu (Soetisna et al., 1998). Musim buahnya 2 tahun sampai 5 tahun sekali dan tidak menentu (Jǿker, 2002). Salah satu alternatif metode yang sudah dikenal luas untuk memperbanyak jenis ini dalam jumlah banyak dan terus-menerus adalah melalui teknik perbanyakan tanaman secara vegetatif, misalnya stek (Subiakto et al., 2007).

Keberhasilan pertumbuhan stek dipengaruhi oleh faktor bahan tanaman, lingkungan dan zat pengatur tumbuh (Hartmann et al., 1997). Faktor bahan tanaman meliputi karakter genetik, kandungan cadangan makanan, ketersediaan air, hormon endogen, tingkat juvenlitas dan umur tanaman. Faktor lingkungan yang mempengaruhi keberhasilan penyetekan, antara lain: media perakaran, kelembaban, suhu, intensitas cahaya dan teknik penyetekan.

Tingkat juvenilitas bahan stek sangat dipengaruhi oleh umur tanaman, dan merupakan salah satu faktor yang menentukan kemampuan perakaran bahan stek (Galopin et al., 1996; Hartmann et al., 1997). Tingkat juvenilitas pucuk bahan 
stek umumnya menentukan kandungan auksin, dan nutrisi bahan stek. Tanaman yang tua dan sulit berakar dapat direjuvensi. Salah satu teknik rejuvensi adalah penyambungan (grafting) tunas tua dengan tanaman bawah yang berumur muda secara berseri hingga tunas mampu berakar (Hartmann et al., 1997). Saat ini, informasi ilmiah mengenai tingkat juvenilitas pada beberapa umur bahan stek serta hubungannya dengan keberhasilan perakaran stek meranti masih sangat terbatas sehingga perlu dilakukan penelitian tersebut, terutama untuk jenis $S$. leprosula.

Penelitian ini bertujuan untuk mempelajari hubungan antara umur dengan kandungan hara dan auksin bahan stek terhadap keberhasilan stek meranti tembaga.

\section{METODE PENELITIAN}

\section{A. Waktu dan Tempat}

Penelitian dilaksanakan mulai bulan Juni 2008 sampai dengan bulan April 2009 di Laboratorium Silvikultur, Pusat Penelitian dan Pengembangan Hutan dan Konservasi Alam.

\section{B. Bahan Tanaman}

Bahan penelitian menggunakan pucuk vertikal (orthotrop) dari tanaman $S$. leprosula yang berumur $\leq 2$ tahun (tinggi $0,58 \mathrm{~m}$; diameter $5,39 \mathrm{~cm}$ ), umur 10 tahun (tinggi 22,50 m, diameter 45,85 cm), dan umur 25 tahun (tinggi 30,67 m; diameter 53,18 cm). Setiap kelas umur terdiri dari 45 stek pucuk dengan 4 kali ulangan. Bahan stek dikumpulkan dari persemaian dan Kebun Percobaan Dramaga, Bogor, Jawa Barat.

\section{Teknik Penyetekan}

Bahan stek ditanam pada media campuran sabut kelapa dan sekam padi steril dengan perbandingan 2:1 (v/v) dalam potray ukuran 4,5 x 4,5 x $12 \mathrm{~cm}$. Sebelum ditanam bagian bawah stek dibubuhi hormon pengatur tumbuh rootone-F (napthalene acetamide sebanyak 0,0678\%, methyl-1-napthalene acetic acid sebanyak $0.033 \%$, methyl -1-napthalene acetamide sebanyak $0.013 \%$, indole - 
3- butyric acid 0,057\% dan tetramethilthiuram disulfida sebanyak $4 \%$. Perakaran stek dilakukan di rumah kaca yang dilengkapi dengan sistem pendingin (KOFFCO System). Pengamatan akhir dilakukan setelah stek berumur 3 bulan setelah tanam. Pengamatan dilakukan terhadap persen stek berakar, stek segar, stek bertunas, panjang akar, jumlah akar, dan biomasa akar.

\section{Analisis Hara dan Auksin}

Unsur hara bahan stek yang diukur meliputi unsur karbon $(\mathrm{C})$, nitrogen $(\mathrm{N})$, pospor $(\mathrm{P})$, kalium $(\mathrm{K})$, dan nisbah $\mathrm{C} / \mathrm{N}$. Pengujian kandungan hara dilakukan di Laboratorium Departemen Ilmu Tanah dan Sumberdaya Lahan, Fakultas Pertanian IPB. Kandungan C ditetapkan dengan menggunakan metode C-Mobius, sedangkan unsur $\mathrm{N}$ ditetapkan menggunakan metode Kjeldahl. Kandungan $\mathrm{P}$ ditetapkan dengan metode bluemolybdate menggunakan alat spektrofotometer $U V$-Vis, dan kandungan $\mathrm{K}$ ditetapkan menggunakan alat flame photometer. Nisbah $\mathrm{C} / \mathrm{N}$ dihitung berdasarkan kandungan unsur $\mathrm{C}$ dan $\mathrm{N}$ bahan stek. Kandungan auksin diukur dengan menggunakan HPLC (High Performance Liquid Chromatography) dengan detektor UV-Vis di Laboratorium Pengujian, Balai Besar Penelitian dan Pengembangan Pascapanen Pertanian dengan metode Linskens dan Jackson (1987).

\section{E. Analisis Data}

Data yang diperoleh dianalisis dengan ANOVA, selanjutnya dengan DMRT dan Biplot sebagai uji lanjut pada taraf kepercayaan 95\% menggunakan program SAS 9.1.

\section{HASIL DAN PEMBAHASAN}

\section{A. Respon Umur Sumber Bahan Stek terhadap Keberhasilan Perakaran Stek Shorea leprosula}

Umur sumber bahan stek sangat berpengaruh terhadap keberhasilan perakaran stek S. leprosula disamping faktor genetik dan lingkungan. Tanaman muda yang berumur $\leq 2$ tahun dapat menghasilkan persen stek segar, persen stek bertunas, persen stek berakar, jumlah akar, dan berat kering akar yang lebih tinggi 
dibandingkan dengan tanaman dewasa (Tabel 1). Tanaman muda menghasilkan persen stek berakar rata-rata 88,33\%, sedangkan tanaman yang berumur 10 tahun dan 25 tahun masing-masing hanya menghasilkan rata-rata persen tumbuh sebesar $12,22 \%$ dan 2,22\%. Bahan stek yang sudah dewasa sulit untuk melakukan dediferensiasi, sehingga bahan stek mudah busuk dan mati sebelum stek tumbuh. Pada kondisi ruang pengakaran yang optimal, sumber bahan stek berumur $<2$ tahun mampu menghasilkan stek segar 100\% dan stek bertunas 92,78\% sedangkan sumber bahan stek berumur 10 tahun hanya mampu menghasilkan stek segar $36,67 \%$ dan stek bertunas $16,67 \%$. Untuk itu, bahan stek dari tanaman yang sudah dewasa perlu dilakukan rejuvenasi terlebih dahulu sebelum digunakan sebagai stek. Teknik rejuvenasi bahan stek antara lain dengan cara: 1) memunculkan tunas adventif dari bagian akar, 2) memotong tunas apikal atau tunas samping kemudian menyemprotnya dengan larutan sitokinin atau gibberellin, 3) mendorong tumbuhnya tunas sphaeroblasts pada pohon tua dengan cara memotong cabang atau melakukan pembengkokan batang pada kebun pangkasan, 4) menyambungkan tunas tua dengan tanaman bawah yang berumur muda secara berseri hingga tunas mampu berakar, 5) melakukan subkultur secara berseri dengan teknologi kultur jaringan (Galopin et al., 1996; Hartmann et al., 1997).

Tabel (Table) 1. Rata-rata pertumbuhan stek S. leprosula pada tiga kelas umur pohon induk sumber bahan stek (The average of the growth of $S$. leprosula cutting at three different age of mother trees)

\begin{tabular}{|c|c|c|c|}
\hline \multirow[b]{2}{*}{ Parameter (Parameter) } & \multicolumn{3}{|c|}{ Umur pohon induk (Age of mother trees) } \\
\hline & $\begin{array}{c}\leq 2 \text { tahun } \\
\text { (years) }\end{array}$ & $\begin{array}{c}10 \text { tahun } \\
\text { (years) }\end{array}$ & $\begin{array}{c}25 \text { tahun } \\
\text { (years) }\end{array}$ \\
\hline $\begin{array}{l}\text { Stek segar } \\
\text { (fresh cutting) (\%) }\end{array}$ & $100,00 \pm 0,00^{\mathrm{a}}$ & $36,67 \pm 8,11^{b}$ & $35,56 \pm 3,39^{b}$ \\
\hline $\begin{array}{l}\text { Stek bertunas } \\
\text { (shooted cutting) (\%) }\end{array}$ & $92,78 \pm 5,56^{\mathrm{a}}$ & $16,67 \pm 11,26^{b}$ & $9,44 \pm 2,13^{b}$ \\
\hline $\begin{array}{l}\text { Stek berakar } \\
\text { (rooted cutting) }(\%)\end{array}$ & $88,33 \pm 5,56^{a}$ & $12,22 \pm 9,85^{b}$ & $2,22 \pm 1,81^{\mathrm{b}}$ \\
\hline $\begin{array}{l}\text { Jumlah akar } \\
\text { (number of root) }\end{array}$ & $7,00 \pm 1,73^{\mathrm{a}}$ & $4,00 \pm 2,00^{a b}$ & $1,33 \pm 0,58^{\mathrm{b}}$ \\
\hline $\begin{array}{l}\text { Panjang akar } \\
(\text { length of root })(\mathrm{cm})\end{array}$ & $8,78 \pm 0,63^{a}$ & $3,63 \pm 2,65^{b}$ & $0,50 \pm 0,00^{b}$ \\
\hline $\begin{array}{l}\text { Berat akar } \\
\text { (weight of root) }(\mathrm{g})\end{array}$ & $0,107 \pm 0,05^{\mathrm{a}}$ & $0,053 \pm 0,05^{\mathrm{a}}$ & $0,053 \pm 0,05^{\mathrm{a}}$ \\
\hline
\end{tabular}




\begin{tabular}{|l|c|c|c|}
\hline $\begin{array}{l}\text { Berat kering akar } \\
(\text { dry weight of root })(\mathrm{g})\end{array}$ & $0,051 \pm 0,02$ & $0,021 \pm 0,02$ & $0,021 \pm 0,02$ \\
\hline
\end{tabular}

Keterangan (Remarks): Angka yang diikuti oleh huruf yang sama pada kolom yang sama menujukkan tidak berbeda nyata pada taraf $5 \%$ berdasarkan Uji Jarak Berganda Duncan (Value followed by the same letters in the same colomn are not significantly at level of $5 \%$ base on Duncan Multiple Range Test)

Kemampuan bahan stek untuk berakar menurun seiring dengan semakin bertambahnya umur tanaman. Hal ini sesuai dengan penelitianpenelitian pada tanaman hutan lainnya. Bahan stek Pinus banksiana umur 3 bulan ke 12 tahun perakarannya turun dari 80-95\% menjadi 0-18\%, dan bahan stek umur 4 - 6 tahun menghasilkan 40-30\% (Browne et al., 1997). Stek Prosopis cineraria umur 6 bulan yang diberi auksin konsentarsi 1000 dan 4000 ppm menghasilkan persen berakar $60 \%$, sedangkan bahan stek umur 8 tahun dengan auksin yang sama menghasilkan persen akar 35\% (Arya et al., 1994).

Dengan demikian untuk menyediakan bibit meranti melalui stek hanya dapat dilakukan dengan menggunakan bahan tanaman yang berumur muda (juvenil). Untuk memperbanyak tanaman meranti yang berumur dewasa $(\geq 10$ tahun) perlu dilakukan rejuvenasi bahan stek dengan melakukan pemangkasan, penyambungan, pemberian hormon tumbuh dan pemupukan nitrogen pada tanaman induk atau penambahan auksin pada stek (Hartmann et al., 1997).

\section{B. Kandungan Hara Bahan Stek}

Pertumbuhan tunas dan akar stek secara langsung maupun tidak langsung dipengaruhi oleh komposisi kimia bahan stek, lingkungan dan interaksinya. Kandungan kimia bahan stek bervariasi untuk setiap tanaman induk maupun umur yang berbeda. Hasil analisis kandungan hara menunjukkan adanya perbedaan yang nyata pada $\mathrm{p}<0,05$ antara bahan stek muda dan bahan stek dewasa terutama pada kandungan $\mathrm{C}, \mathrm{N}, \mathrm{P}$ dan nisbah $\mathrm{C} / \mathrm{N}$ (Gambar 1).

Kandungan unsur $\mathrm{N}$ dalam batang bahan stek yang berumur muda lebih rendah dibandingkan dengan dalam bahan stek dewasa, sedangkan kandungan C-nya relatif sama. Dengan demikian bahan stek muda dapat menghasilkan 
nisbah $\mathrm{C} / \mathrm{N}$ yang lebih tinggi dibandingkan dengan bahan stek dewasa. Nilai nisbah $\mathrm{C} / \mathrm{N}$ bahan stek sangat berpengaruh terhadap pertumbuhan akar stek Heritiera spp. (Das et al.,1997), Thunbergia grandiflora (Hussein, 2008), Rosa multiflora 'Brooks 56' (Hambrick et al., 1991), tetapi tidak dapat diperkirakan secara pasti berapa nilai $\mathrm{C} / \mathrm{N}$ yang terbaik untuk perakaran stek (Struve 1981, dalam Hambrick et al., 1991). Nisbah C/N bahan stek terbaik terhadap perakaran stek Rosa multiflora adalah 12:1 (Hambrick et al., 1991). Pada tanaman Ulnus villosa terjadi perakaran terbaik ketika bahan stek memiliki kandungan gula, karbohidrat total dan aktifitas enzim peroxidase yang tinggi dengan kandungan $\mathrm{N}$ yang rendah (Bhardwaj and Mishra, 2005).
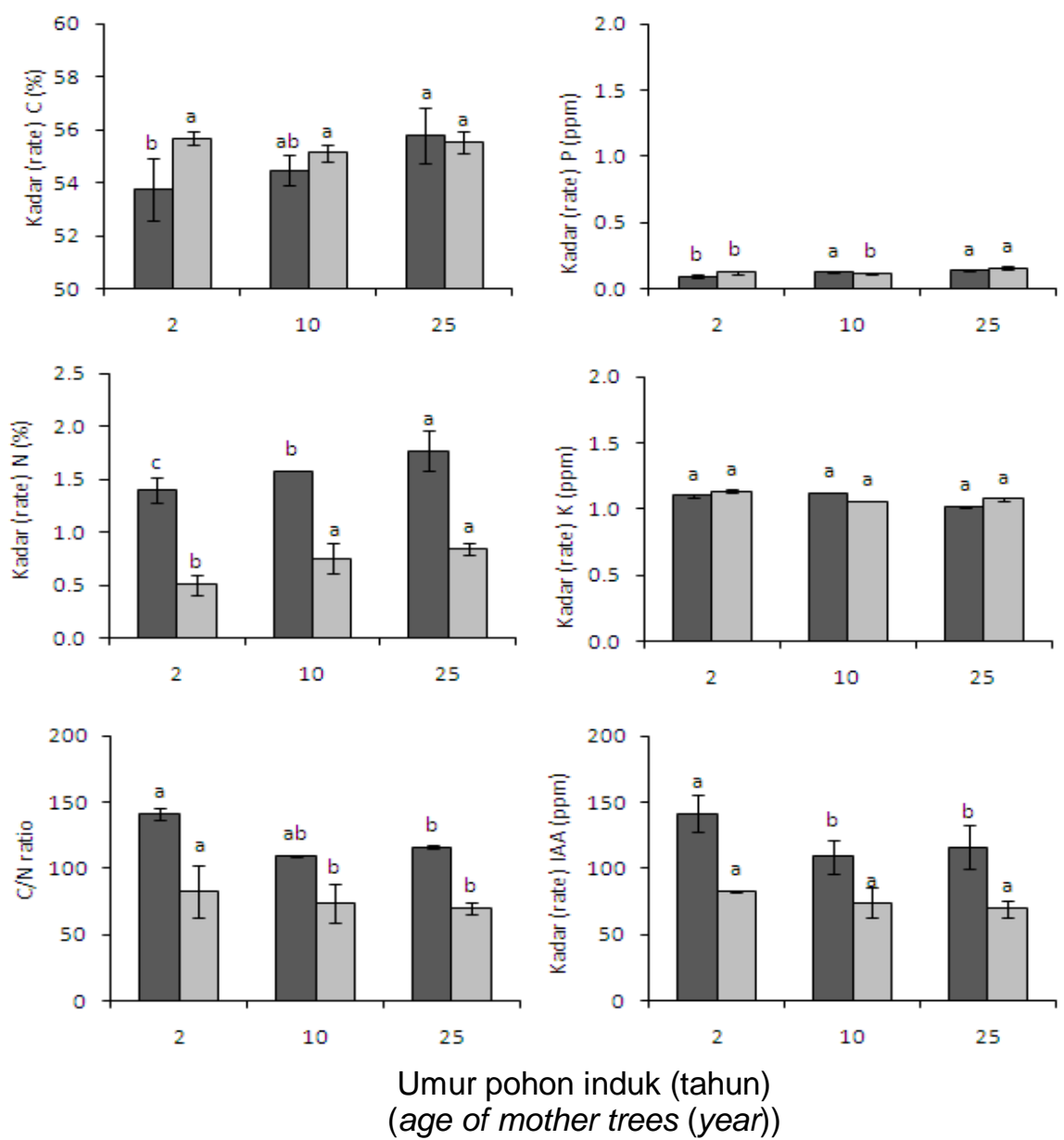

Gambar (Figure) 1. Kandungan hara dan auksin IAA dalam bahan stek meranti tembaga (Nutrition and auxin IAA content of S. leprosula's cutting material). = daun (leaves),$\quad=$ batang $($ stem $)$ 
Daun muda dan daun dewasa tanaman E. polyanthemos dan $E$. regnans memiliki karbohidrat tidak berbeda nyata (Gras, 2005). Kandungan nitrogen tanaman Juniperus occidentalis Hook muda dan dewasa relatif sama pada bulan Agustus (kadar air tanah terbatas) yaitu masing-masing 1,17\% dan $1,35 \%$, sedangkan pada bulan Juli (kadar air tanah tinggi), tanaman dewasa mengandung nitrogen yang lebih tinggi $(1,05 \%)$ dibandingkan dengan tanaman muda $(0,95 \%)$ (Miller et al., 1995). Dengan demikian pembuatan stek yang baik dapat dilakukan pada saat akhir musim panas, karena pada saat itu kadar air tanah rendah yang dapat menghentikan perpanjangan sel dan meningkatkan nisbah $\mathrm{C} / \mathrm{N}$ tanaman.

\section{Kandungan Auksin Bahan Stek}

Fitohormon kelompok auksin merupakan faktor utama yang mempengaruhi tingginya persen tumbuh stek tanaman meranti. Kandungan auksin IAA dalam bahan stek meranti umur $\leq 2$ tahun lebih tinggi dibandingkan dengan bahan stek umur 10 tahun dan 25 tahun terutama pada bagian daun, sedangkan kandungan auksin IAA pada batang relatif sama untuk semua kelas umur (Gambar 1). Tingginya kandungan auksin endogen dalam bahan stek dapat meningkatkan kemampuan perakaran stek meranti. Bahan stek meranti dari tanaman muda ( $\leq 2$ tahun) dapat menghasilkan persen akar, persen tunas, persen segar, jumlah akar, dan panjang akar yang lebih tinggi dibandingkan dengan bahan stek dari tanaman yang telah berumur $\geq 10$ tahun (Tabel 1).

Hormon tumbuh auksin sangat penting peranannya dalam proses inisiasi pembentukan akar adventif (Hackett, 1988). Keberadaan auksin IAA dalam daun lebih berperan terhadap keberhasilan perakaran stek meranti dibandingkan dengan auksin IAA dalam batang (Gambar 1 dan Gambar 2). Auksin paling banyak diproduksi di bagian pucuk apikal dan bagian lain seperti daun muda dan primordial daun kemudian dialirkan ke bagian bawah tanaman (Woodward and Bartel, 2005). Pada tanaman Abies normanniana, kandungan auksin IAA tertinggi terdapat pada bagian tengah pucuk plagiatrop maupun orthotrop (Vierskov et al., 2007), dan memiliki pola yang sama 
terhadap musim dan pertumbuhan stek batang Arundo donax (Wijte et al., 2005).

\section{Pola Hubungan antara Kandungan Hara dan Auksin dengan Keberhasilan Perakaran Stek}

Keberhasilan perakaran stek sangat dipengaruhi oleh kandungan hara dan auksin bahan stek. Hasil analisis biplot (Gambar 2) menunjukkan bahwa peubah persen stek berakar (A) dengan kandungan IAA dalam daun (F) dan nisbah $\mathrm{C} / \mathrm{N}$ dalam batang (Q) membentuk sudut yang kecil. Hal ini menunjukkan bahwa peubah tersebut mempunyai hubungan (korelasi) positif yang cukup erat. Dengan arti makin tinggi nilai peubah (IAA dan nisbah $\mathrm{C} / \mathrm{N}$ ) maka cenderung diikuti pula persen stek berakar yang makin tinggi (Gambar 2). Peubah lainnya cenderung mengelompok di titik pusat, berarti pengaruh umur terhadap peubah tersebut sangat rendah.

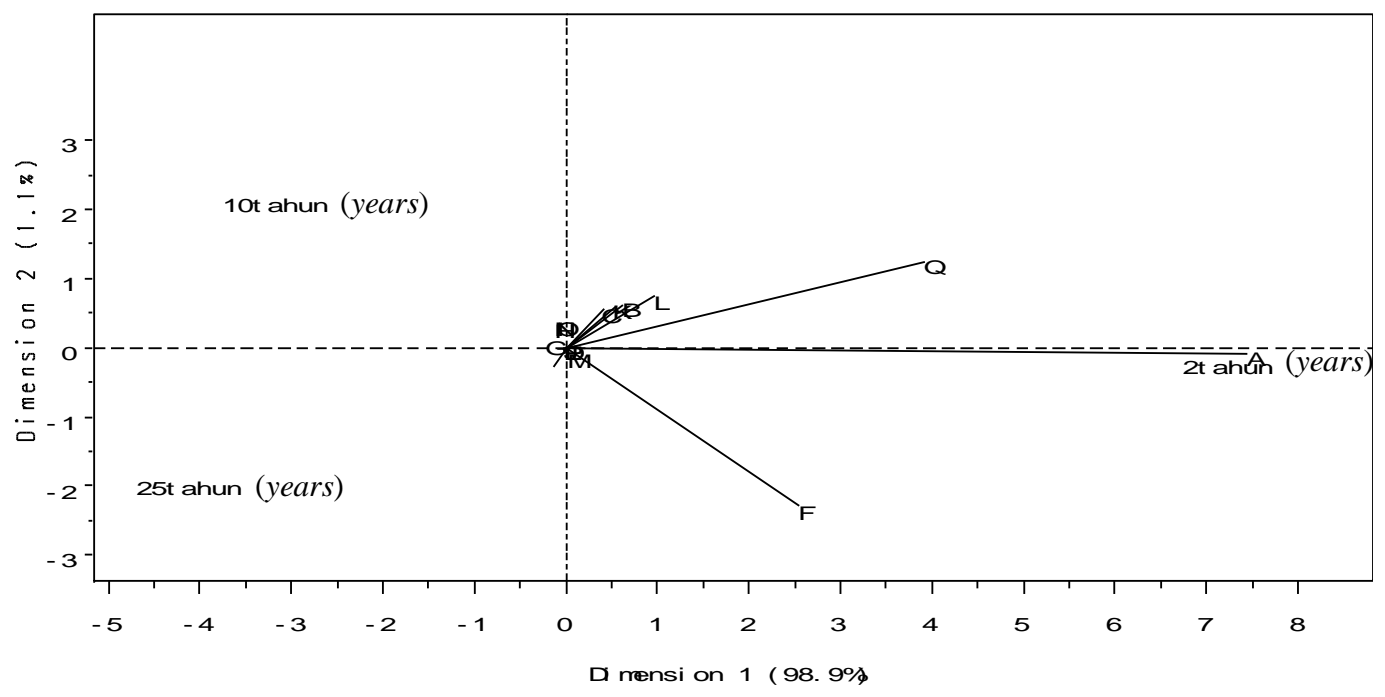

Gambar (Figure) 2. Hasil biplot peubah dengan umur bahan stek S. leprosula. A: stek (biplot result of variabel and age of $\mathrm{S}$. leprosula cutting material. B: panjang akar (length of root), C: jumlah akar (root number), D: berat akar (weight og root), E: berat kering akar (dry weight of root), F: IAA daun (IAA on leaf), G: C daun (Carbon on leaf), $\mathrm{H}: \mathrm{N}$ daun (nitrogen on leaf) I: P daun (fosfor on leaf), $\mathrm{J}$ : $\mathrm{K}$ daun (kalium on leaf), $\mathrm{K}$ : nisbah $\mathrm{C} / \mathrm{N}$ daun (C/N ratio of leaf), L: IAA batang (IAA on stem), M: C batang (carbon on stem), $\mathrm{N}: \mathrm{N}$ batang (nitogen on stem), $\mathrm{O}: \mathrm{P}$ batang (forfor on stem), P: K batang (kalium on stem), Q: nisbah $\mathrm{C} / \mathrm{N}$ batang $(\mathrm{C} / \mathrm{N}$ ratio of stem). Dimensi vertikal 
1,1\% dan dimensi horizontal 98,9\% dengan skala 0,973077 (observasi/peubah). Vertical dimencion 1,1\% and horizontal dimention 98,9\% at scale 0.973077(observation/variabel)

Dengan demikian, faktor utama yang mempengaruhi tingginya persen tumbuh stek $S$. leprosula adalah kandungan auksin IAA (F) dalam daun dan nisbah $\mathrm{C} / \mathrm{N}(\mathrm{Q})$ dalam batang (Gambar 2 dan Gambar 3). Bahan stek meranti berumur $\leq 2$ tahun mengandung IAA dalam daun sebanyak 141,073 ppm dan nisbah $\mathrm{C} / \mathrm{N}$ batang sebesar 113,06 dapat menghasilkan stek berakar sebanyak $88,33 \%$, sedangkan bahan stek yang berumur $\geq 10$ tahun mengandung IAA dalam daun 116,167 ppm dan nisbah $\mathrm{C} / \mathrm{N}$ batang sebesar 75,10 hanya dapat menghasilkan stek berakar sebanyak 12,22\% (Tabel 1, Gambar 1 dan Gambar 3). Peningkatan kandungan auksin IAA maupun IBA dapat meningkatkan jumlah akar lateral dan adventif pada Arabidopsis thalianan (Woodward and Bartel, 2005), sedangkan nisbah $\mathrm{C} / \mathrm{N}$ merupakan faktor penting terhadap kemampuan perakaran stek tanaman Thunbergia grandflora (Roxb ex Rottl) Roxb walaupun kandungan auksinnya tinggi (Hussein, 2008), stek Heritiera spp. (Das et al., 1997) dan stek Rosa multiflora 'Brooks 56' (Hambrick et al., 1991).
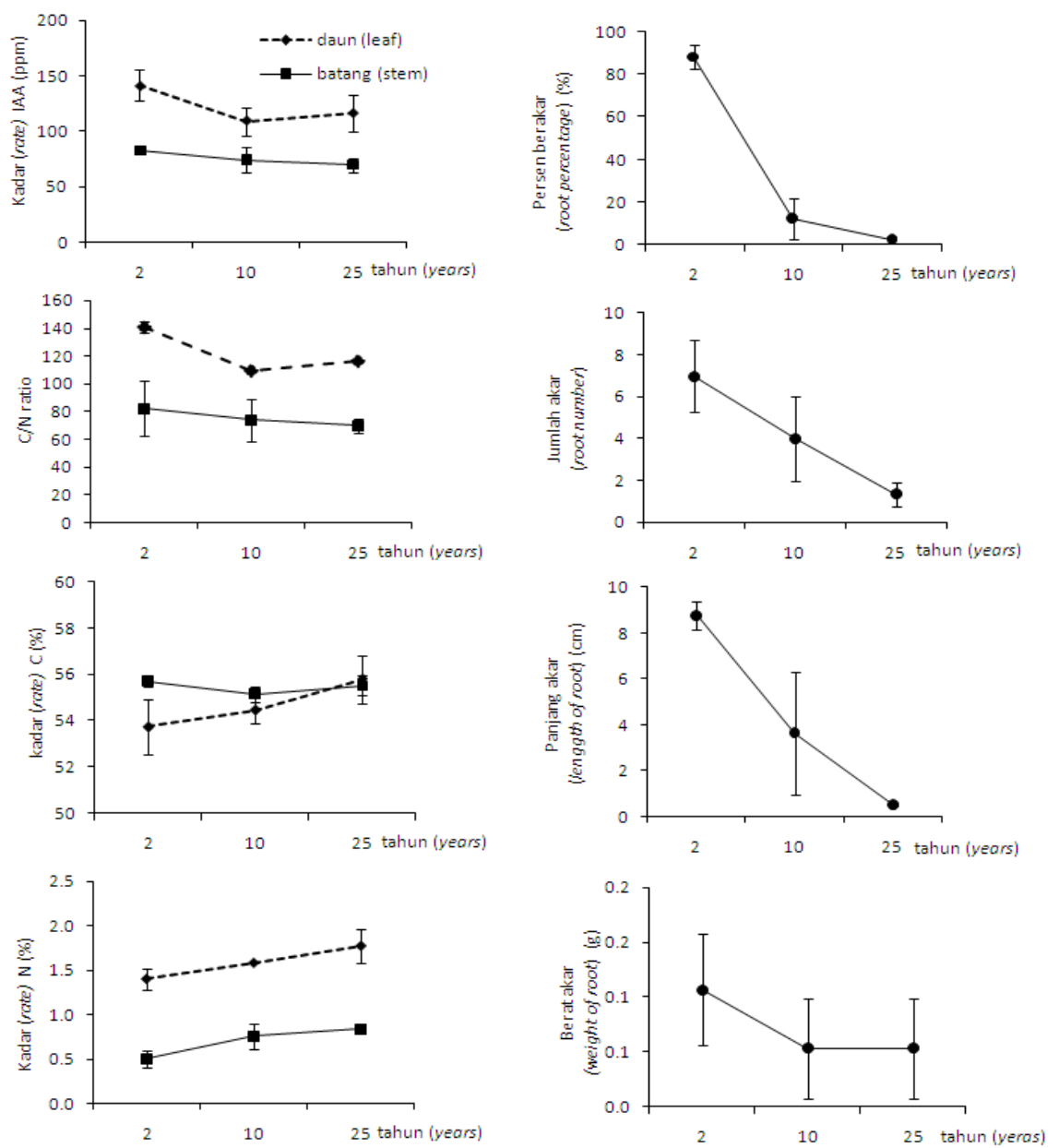
Gambar 3. Pola hubungan antara kandungan auksin IAA dan hara bahan stek dengan keberhasilan perakaran stek S. leprosula (Relation pattern between auxin IAA and nutrition content with the success of rooted cuttings of $\mathrm{S}$. leprosula)

Peran unsur $\mathrm{N}$ terhadap perarakan stek terjadi secara tidak langsung (Das et al., 1997; Bollmark et al., 1999; Druege et al., 2000). Penambahan nitrogen berkorelasi positif dengan sukrosa dan fruktosa dan berkorelasi negatif dengan karbohidrat dan dapat meningkatkan jumlah akar adventif sek tanaman Crysanthemum (Dendrathema grandiflorum) (Druege et al., 2000). Penelitian Bollmark et al. (1999) melaporkan bahwa pasokan nitrogen menyebabkan perubahan konsentrasi sukrosa dan pati yang bervariasi dalam seluruh organ tanaman Salix viminalis, unsur N mempengaruhi status karbohidrat non struktural dalam pertumbuhan stek, penurunan pasokan nitrogen dapat mendorong penimbunan karbohidrat dalam daun yang masih tumbuh. Dengan demikian untuk meningkatkan kemampuan perakaran stek tanaman S. leprosula dewasa dapat ditambah auksin buatan seperti IBA (indole - 3- butyric acid) dari luar (Aminah et al., 1995).

\section{KESIMPULAN DAN SARAN}

\section{A. Kesimpulan}

1. Semakin muda umur sumber bahan stek cenderung mengandung hormon tumbuh IAA dan nisbah $\mathrm{C} / \mathrm{N}$ yang tinggi, sehingga menghasilkan persentase keberhasilan perakan stek S. leprosula yang tinggi.

2. Sumber bahan stek meranti umur $\leq 2$ tahun menghasilkan persen berakar dan biomasa akar stek yang lebih tinggi dibandingkan dengan sumber bahan stek yang sudah tua ( $\geq 10$ tahun), sejalan dengan tingginya kandungan auksin IAA dan nisbah $\mathrm{C} / \mathrm{N}$. 
3. Sumber bahan stek umur 10 tahun dan 25 tahun masih mampu berakar (12\% dan 2\%), sehingga teknik stek dapat digunakan untuk perbanyakan terseleksi pada klon-klon terseleksi pada program pemuliaan yang umumnya dilakukan pada umur sekitar 10 tahun.

\section{B. Saran}

Untuk meningkatkan persen berakar sumber bahan stek di atas 10 tahun dapat dilakukan dengan teknik rejuvenasi, antara lain dengan teknik penyambungan (grafting).

\section{DAFTAR PUSTAKA}

Aminah, H., J.Mc.P. Dick, and J. Grace. 1997. Rooting of Shorea leprosula stem cutting decreases with increasing leaf area. Forest Ecology and Management 91:247-254.

Aminah, H., J.Mc.P. Dick, R.R.B. Leakey, J.Grace, and R.I. Smith. 1995. Effect of indole butyric acid (IBA) on stem cuttings of Shorea leprosula. Forest Ecology and Management 72:199-206.

Appanah, S. and G. Weinland. 1993. Planting quality timber trees in Peninsular Malaysia. Review. Malayan Forest Records No.38. Forest Reseach Institute Malaysia. Kepong. Kuala Lumpur. Malaysia.

Arya, S., R. Tomar and P. Toky. 1994. Effect of plant age and auxin treatment on rooting response in stem cuttings of Prosopis cineraria. Journal of Arid Environments 27: 99-103.

Ashton, P.S. 1982. Dipterocarpaceae. Flora Malesiana. Ed ke-1 (9): 237-52.

Bauer, L.M., M.E. Johnstone and R.R. Williams. 1999. Plant genotype, juvenility and mechanisms of inhibition of rooting Perssoonia virgata $\mathrm{R} . \mathrm{Br}$. cuttings. Australian Journal of Experimental Agriculture. 39: 1029-1034.

Bhardwaj and V.K. Mishra. 2005. Vegetative propagation of Ulmus villosa: effects of plant growth regulators, collection time, type of donor and position of shoot on adventitious root formation in stem cuttings. New Forest 29:105106. (Abstract).

Bollmark, L., L. Sennerby-Forsse and T. Ericsson. 1999. Seasonal dynamics and effects of nitrogen supply rate on nitrogen and carbohydrate reserves in cutting-derived Salix viminalis plants. Canadian Journal of Forest Research. 29: 85-94.

Browne, R.D., C.G. Davidson, T.A. Steeves and D.I. Dunstan. 1997. Effect of ortet age on adventitious rooting of jack pine (Pinus banksiana) long-shoot cuttings. Canadian Journal of Forest Research 27: 91-96. 
Das, P., U.C. Basak and A.B. Das. 1997. Metabolic changes during rooting in pregirdled stem cuttings and air-layers of Heritiera. Botanical Bulletin of Academia Sinica 38: 91-95.

Druege, U., S..Zerche, R. Kadner and M. Ernst. 2000. Relation between nitrogen status, carbohydrate distribution and subsequent rooting of Crysanthemum cuttings as affected by pre-harvest nitrogen supply and cold-storage. Annals of Botany 85:687-701.

Galopin, G., F. Beaujard and M. Gendraud. 1996. Intensive production of juvenile cuttings by mother microplant culture in Hidrangea macrophylla "Leuchtfeuer". Canadian Journal of Botany. 74: 561-567.

Gras, E.K., J. Read, C.T. Mach, G.D. Sansona and F.J. Lissold. 2005. Herbivore damage, resource richness and putative defences in juvenile versus adult eucalyptus leaves. Australian Journal of Botany 53: 33-44.

Hackett, W.P. 1988. Donor plant maturation and adventitious root formation. Di dalam: Davis D, Haissig BE, Sankhla N, editor. Adventitious Root Formation in Cuttings. Oregon: T. Dioscorides Press.

Hambrick, C.E.III., F.T.Jr. Davies and H.B. Perberton. 1991. Seasonal changes in carbohydrate/nitrogen levels during field rooting of Rosa multiflora 'Brooks 56' hardwood cuttings. Scientia Horticultural 46:137-146.

Hartmann, H.T., D.E. Kester, F.T. Davies and R.L. Geneve. 1997. Plant Propagation: Principles and Practices. Ed ke-6. Prentice Hall. Englewood Cliffs. New Jersey.

Hussein, M..M..M. 2008. Studies on the rooting and the consequent plant growth on the stem cuttings of Thunbergia grandiflora (Roxb. ex Rottl.) Roxb. 2effect of indole-3-butyric acid. World Journal of Agricultural Sciences 4 (S): 811-817.

Jǿker, D. 2002. Shorea leprosula Miq. Informasi Singkat Benih No.28. Indonesia Forest Seed Project. Bandung.

Linskens, H.F. and J.F. Jackson. 1987. High Performance Liquid Chromatography in Plant Sciences. In Moleculer Methods of Plant Analysis. Volume 5. Springer-Verlag. Berlin Heidelberg. New york. London. Paris. Tokyo.

Miller, P.M., L.E. Eddleman, and J.M. Miller. 1995. Juniperus occidentalis juvenile foliage: advantages and disadvantages for a stress-tolerant, invasive conifer. Canadian Journal of Forest Research 25: 470-479.

Soetisna, D., D.E. Rantau and E.S. Mulyaningsih. 1998. Desication and storage trial of recalcitrant seed: a case study of Pometia pinnata and Shorea leprosula. In: Marzalina, M., K.C. Khoo, N. Jayanthi, F.Y. Tsan and B. Krishnapillay, Editor. Recalcitrant seeds. Proceedings of the conference IUFRO Seed Symposium, Kuala Lumpur, 12-15 October 1998.

Struve, D.K. 1981. The relationship between carbohydrates, nitrogen and rooting of stem cutting. Plant Propagation. 27:6-7.

Subiakto, A., R. Effendi dan Ernayati. 2007. Ketersediaan IPTEK pembibitan, penanaman dan pemeliharaan hutan tanaman dipterokarpa. Di dalam: Parthama 
P. dan N. Juliaty (editor). Prosiding Seminar Pengembangan Hutan Tanaman Dipterokarpa dan Ekspose TPTII/SILIN. Samarinda 4-5 September 2007. Samarinda: Balai Besar Penelitian Dipterokarpa. Hlm 17-27.

Veierskov, B., H.N. Rasmussen, B..Eriksen and J. Hansen-Møller. 2007. Plagiotropism and auxin in Abies nordmanniana. Tree Physiology 27: 149153.

Wijte, A.H., T. Mizutani, E.R. Motamed, M.L. Merryfield, D.E. Miller and D.E. Alexander. 2005. Patterns in rooting by stem fragments of the invasive giant reed, Arundo donax (Poaceae).International Journal of Plant Sciences 166 (3):507-517.

Woodward, A.W., and B. Bartel. 2005. Auxin: Regulation, Action, and Interaction. Invited Review. Annals of Botany 95: 707-735. 